\title{
ダム貯水池の濁質除去に関する水理学的研究 \\ Hydraulic study of removing turbid water in dam reservoir
}

$\begin{array}{lllllll}\text { 東京理科大学 理工学部 } & \text { 正 } \text { 員 大 西 } & \text { 外 明 } \\ \text { 電源開発株式会社 関西支社 } & \text { 正 } & \text { 員 } \bigcirc & \text { 喜多村 } & \text { 雄 } & -\end{array}$

\section{1. 緒 言}

ダム眝水池は利水と治水の両面で有効に運用されつつあり，現代の人間活動や産業活動に欠くことのでき ないるのとなっている。しかし，一方，近年に至り貯水池の濁り長期化とそれに伴ら水質劣化の傾向が，い くつかの眝水池で発生し，その対応が貯水池開発計画と貯水池繰作計画の両面で重要な課題となっている。 池水の濁り長期化の軽隇策を親規の眝水池開発面加考元ると, 流域の地質, 土地利用状況, 気象や洪水特 性を考虑に入れて，ダム高（貯水池容量）および取・放水口位置・構造を適切に選定するととが必要となる ら。をた，それを貯水池の維持管理の立場から考えると，流域の土地利用状態の管理，池水の現状把握と応 急処置一取・放水量や方法の適正化や各種の濁り対策, 水質改良策等一の実施が必要と考えられる。

以上の様に多様な側面をるつダム貯水池濁り現象に関する研究の一環として, 本論文は, まず実際の貯水 池飞おける池水内の密度分布特性を現地観測データを基に検討し，その結果を基にして，水質変化の主要な 原因の一つとなりらると思われる貯水池内澱み水域の水塊を除去する際飞考慮すべを密度流論的㑯面を明ら かにし，将来の新しい貯水池の設計・計画面へ資しょらとするるのである。

\section{2. 貯水池の密度分布特性の現地観測結果亡考察}

貯水池の濁り長期化とそれ飞伴ら水質変化を軽減する方法としては, 原因となる土砂や有機物質等を池内 に流入させをい面からのるのと, 一たん流入したてれらの物質を除去する面からのるのとが考允られる。後 者の方法で(i)貯水池の水質変化を防止するために, 眝水池内にてれらの物質を長期間停留させをいてと, (ii) 眝水池からの放流飞伴ら下流河川の濁りの継続時間を出来る丈, 短くおさえるととがのぞましい。しかし ての 2 つの事項は互に相反する側面をるっている。すをわち，一般には眝水池の濁水を放流すれば，下流河 川水の濁りは增加すると考えられる。そてで, 両者を両立させ得る可能性を探るために, Kダム眝水池に おける池水の水温と濁度飞関する実測值の検討を行なった。とのととは, 従来の選択取水等飞関する解析的 研究で尊入してを密度分布の仮定条件を検証する上でも興味がもたれるてとである。Kダム眝水池はダム 高約 $100 \mathrm{~m}$, 総貯水量 $130 \times 10^{6} \mathrm{~m}^{3}$, 年間平均旅入流量は約 $1200 \times 10^{6} \mathrm{~m}^{3}$ でり, 安芸ら ${ }^{1)}$ Kょる池水の交

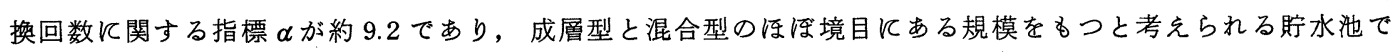
ある。図 1 は, 1978 年 6 月 15 日における眝水池内の水温分布 $\left({ }^{\circ} \mathrm{C}\right)$ と濁度分布 $(\mathrm{ppm})$ を示す。乙の時の 上流河川加ら流入流量 (以後Qinという) は $24 \mathrm{~m}^{3} / \mathrm{sec}$, ダム中腹の取水口加発電所一流入する流量 (以 後Q01といら) は $35.8 \mathrm{~m}^{3} / \mathrm{sec}$, ダム頂からの越流量（以後Q02といら）は $3.8 \mathrm{~m}^{3} / \mathrm{sec}$ でる。水温は池の水 面近傍の薄層で高く, その層から取水口位置標高までの間では厓深均等となり, その下層部では $10^{\circ} \mathrm{C}$ 以下 の低温となっている。ダム越流部に向う流れは典型的な表層密度流を形成し, 上流からの流入水は底層密度 流として流下したのち, 大部分は水平方向に転じて中層密度流となって取水口へ向い, 上流上りの流入水の でく一部は取水口標高以下の底層の澱み層へ流入している状態を示している。ての図で注目されるのは, 中 間層の密度流内の濁度は底層のそれょりる高いてとであり, 池水の密度分布は水温により支配されているこ とを知るととがでをる。

図 2 は, 同年 8 月 23 日の水温と濁度の分布状態であり, $\mathrm{Qin}=11.64 \mathrm{~m}^{3} / \mathrm{sec}, \mathrm{Q}_{01}=11.06 \mathrm{~m}^{3} / \mathrm{sec}, \mathrm{Q} 02=$ $2 \mathrm{~m}^{3} / \mathrm{sec}$ の状態を示す。池水内の乱れが少ない池水成層期に相当し, 取水口標高面に強い水温躍層面があり, 

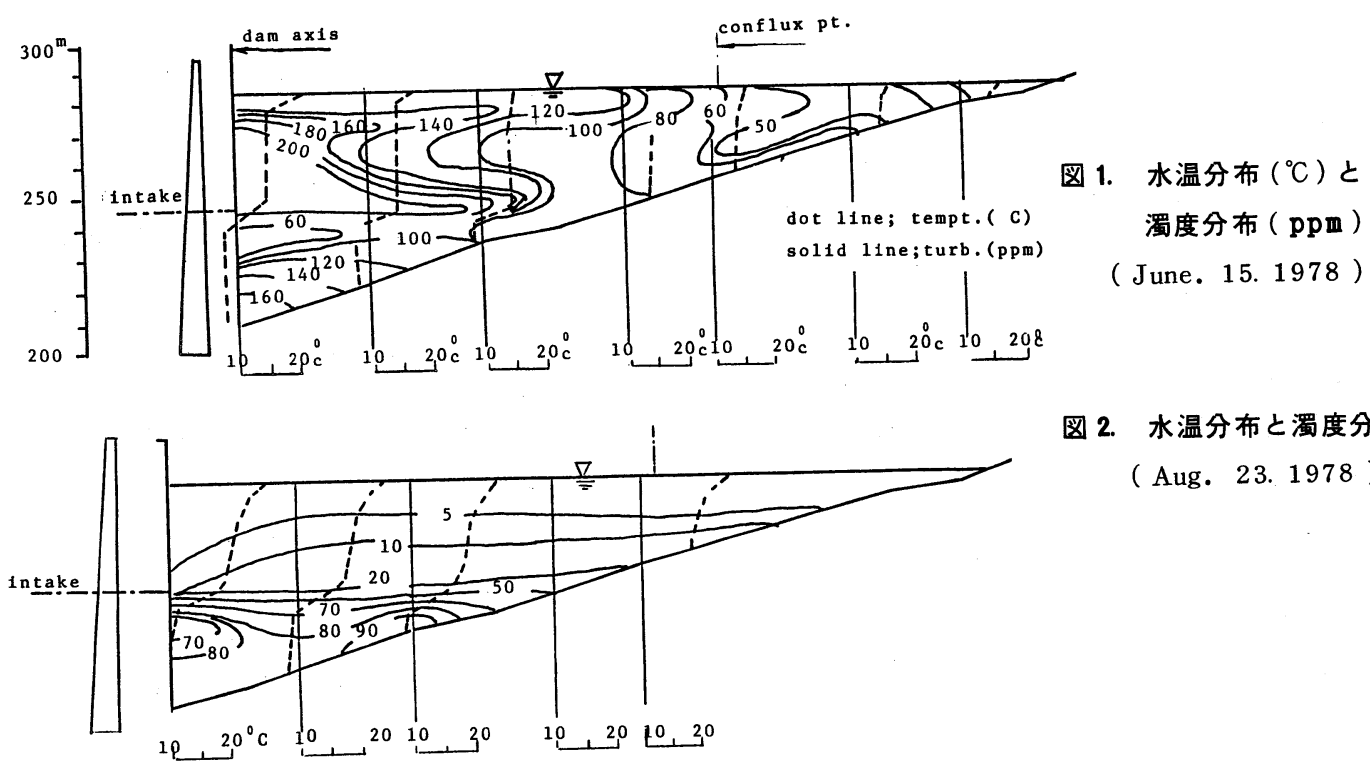

図 2. 水温分布亡濁度分布

(Aug. 23. 1978 )

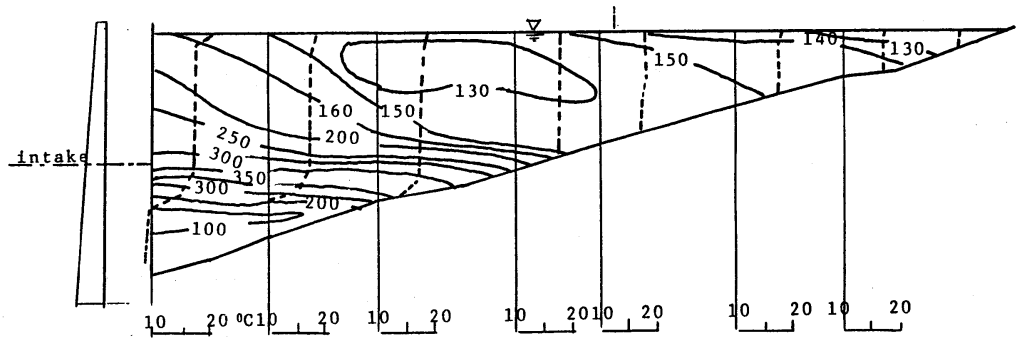

3. 水温分布亡濁度分布

( Sept. 14.1978)

図 4. 水温分布亡濁度分布

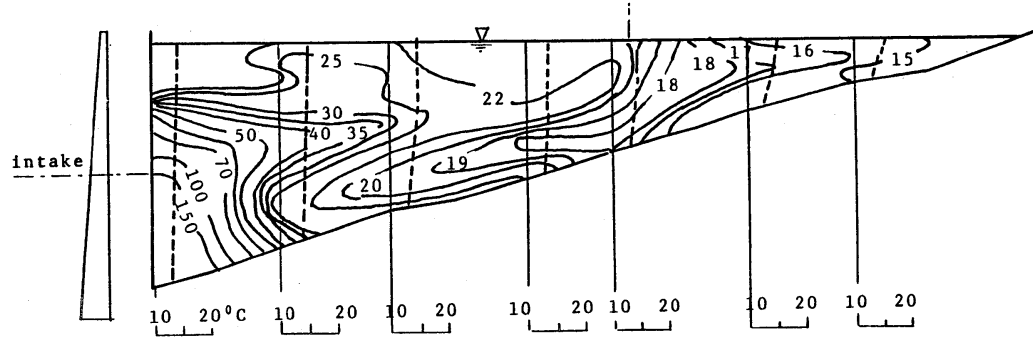

( Nov. 12. 1977)

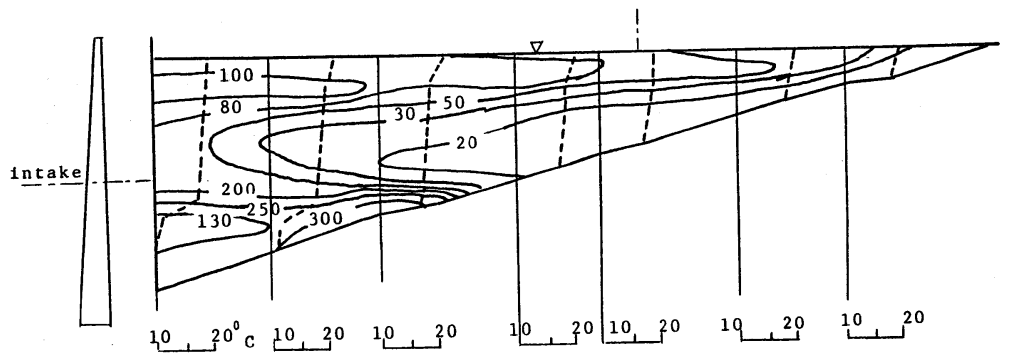

図 5. 水温分布と濁度分布

( Sept. 27.1978) 

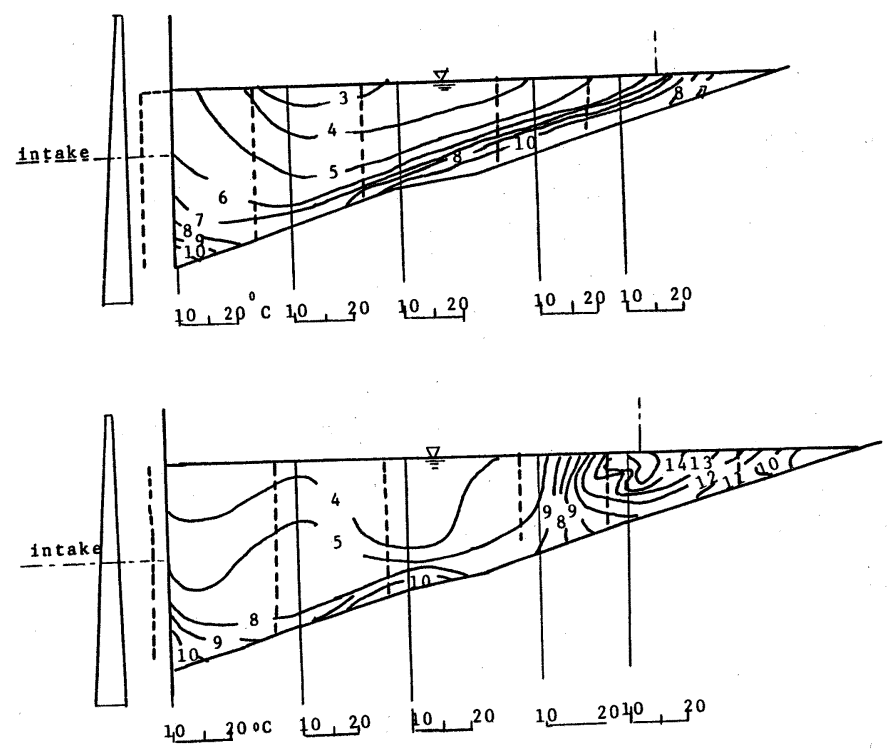

図6. 水温分布と濁度分布

(Feb. 21. 1982 )
図 7. 水温分布と濁度分布

(Feb. 13. 1983 )

濁度は底層汪ど高くなっており，取水口に向ら流れは二成層密度流の様相を示している。乙れらの観測結果 から, ての眝水池では, 流入河川流量が少ない時には, 取水口飞標高以下の水塊は溊み域となり, 外側領域 との交換性が少ない状態に保たれているてとがわかる。この底層の澱み域と上部水域の内の内部境界面の安 定性を知るために，1978 年の最大洪水飞見舞れた 9 月 9 日〜 13 日間の 17 号台風出水 1 日後, 9 月 14 日の 状態を検討した結果が図 3.である。乙の時の流量は $\mathrm{Q}$ in $=260 \mathrm{~m}^{3} / \mathrm{sec}, \mathrm{Q}_{01}=60 \mathrm{~m}^{3} / \mathrm{sec}, \mathrm{Q}_{02}=154 \mathrm{~m}^{3} / \mathrm{sec}$ である。水温蹋層面は, 取水口標高より約 10 数 $\mathrm{m}$ 下方に移動しているるのの,すで安定化しているてとが わかる。こてで注目されるのは, 内部境界面の上・下層飞おける濁度分布であり, 上層では上の部分渒ど濁

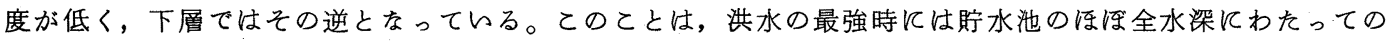
鉛直混合が生じ，上層に移った高濁度の水塊がダム頂もしくは取水口を通して下流へ放出されたてとを示唆 している。図4.は1977 年 11 月 12 日の出水時の測定結果てあるが，ての図により鉛直方向の質量交換の状

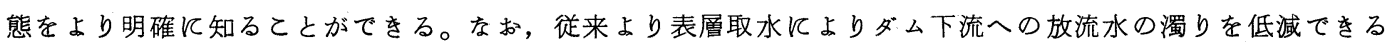
と考えられているが，図3.の結果からは，ダム底部に放流口を設けるととにょり，かえって下流河川水の濁 りを少なくしらるととを予測しうる。図5.は， 17 号出水後 8 日の 9 月 27 日の状態 $\left(\mathrm{Q}\right.$ in $=20 \mathrm{~m}^{3} / \mathrm{sec}, \mathrm{Q} 01$

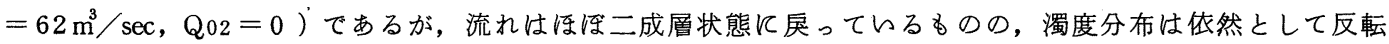
したままであり，底部放水口により比較的濁度の低い底層水を除去しらる可能性を示唆している。ての点に つけては, 後でさらに詳細に論じることとする。

つぎに，貯水池水温が水深方向に一様な場合についてであるが，図6.と図7.飞それぞれ，1982 年 2 月 21 日および 1983 年 2 月 13 日の実測結果を示す。乙の場合，上流上り流入した濁水は底層流として流下する が, ダム背面で底部激み層を形成するととなしに, 取水口からダム下流へ放出されている。乙の傾向は，乙 の貯水池の場合は前記のように密度成層の形成は主として水温差にょってなされ, 濁質の寄与度が少ないて とと, 図6.と図7.の場合は池水の水温が泟淩一様であるととを考慮すれば当然の現象といえる。

以上の検討の結果として次の事がらが推論できる。

(i)通常の状態では，貯水池内の鉊直方向の流体密度分布は水温により支配され，流入土砂の寄与度は少な r。 
(ii)取水口標高面を境にしてその上部が流動層，またそその下部が殷み層となる期間が長い。

(iii)ある程度以上に大をな洪水の流入により, 内部境界面は破壊されて鉊直混合が生じるが, 水温差による 内部境界面は, 比較的早い期間内 - 1 週間以内 - 飞再び形成されて安定化する。しかし, 濁質は早 期に沈降しない状態がある期間は継続する。

(iv)(iii)の状態下では底部放水ロにより, 下流河川水の濁りを低く保ったをを底部澱み層を除去しらる可能性 がある。

(V)冬から初春には, 眝水池内の流動は均等性流体の流れとして取り扱いらると考えられる。

\section{3. 貯水池底部澱み層の排除孔の水理}

上記の $(i i i)$ と $(\mathrm{V})$ を勘案すると, 澱み層内の水塊は少くとも 1 年に 1 回は層外の水と交換されるが, 梅雨期と 台風期の出水時を除く春, 夏, 秋の相当長い期間は池内に停滞するるのと考えられる。特に洪水量の少ない 年, あるいは, 貯水池内人腐敗性の有機物質等が流入して澱み層内に滞ると, その部分の水質を変化させる のみならず, 貯水池の底質も腐敗させて, 貯水池全体の水質劣化の原因の一つとるなりらるので貯水池の水 質保全の見地からは，底部澱み層を除去する方策を講じるととが有用であろらと判断される。たとえば，新 設のダムにおいては, 従来から大ダムで設置されても余り使用されない排砂ゲートを, 澱み層内の水塊除去 の観点から見直す為の設計・製作上の技術開発が有用であると考える。そのような観点から，ててでは溊み 層排除孔を計画する場合を想定して，排除孔容量算定上の考え方について考察を行ら。そのさいに考慮に入 れたい事項は次のとうりである。

(a)溊み層の水だけを除去するとと（溊み層より上部の水は各種の利水目的のために貴重なるのであるため である）。（b)排除孔開放の期間を出来るだけ每くするとと（下流河川への影響を少なくするためである）。 後者の観点からは, 洪水の出水時に合せて排除を計るととがのぞましい。をた, 前節における検討結果(iv)を 参考にすると, 出水後ある期間は下流河川水の濁度を比較的低く保ったををで溊み層の排除を計りらると予 測される。また，出水時には，上層へまを上げられた有機性インパクトのかなりの部分は，ダム越流部が排 除されるであろうと期待される。

前節において記したように, 貯水池内の密度分布は, 出水のピーク時を除けば, 大部分の期間は取水口標 高を境にして 2 成層状態をとるものと仮定してょいので, 図 8 . 亿示すよらな解析モデルを想定する。

最も単純な場合として, 貯水池は幅 $\mathrm{B}$ の長方形であ り，澱み層排除孔す幅 $\mathrm{B}$ ，高さ $\mathrm{d}$ の長方形と仮定する。 眝水池内の上層と下層の梁さと密度をそれぞれ, (h2, $\left.\rho_{2}\right),\left(\mathrm{h}_{1}, \rho_{1}\right)$ とし, 溊み層排除孔から内部境界面まで の鉊直距離を ha とする。洪水の出水時は, 洪水流の一 部をダム頂から越流させるので,その越流水深を hbと する。をた，澱み層排除孔，取水口およびダム越流部 における流量をそれぞれ Qin，Q01，Q02 とする。その 場合, ダム越流量 $\mathrm{Q} 02$ は次式で与えられる。

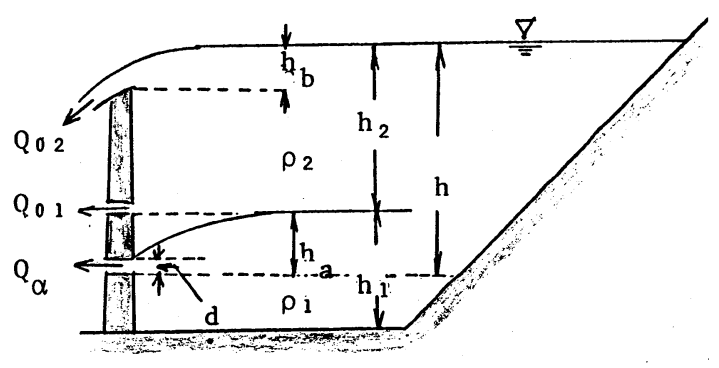

図 8 ダム放流水の 2 成層解析モデル

$$
\mathrm{Q}_{02}=\mathrm{C}_{1} \mathrm{~B} \mathrm{~h}_{\mathrm{b}}{ }^{3 / 2} \quad\left(\mathrm{C}_{1} \text { : 越流部流量係数 }\right)
$$


次に澱み層排除孔からの流量を求めるために, 内部境界面ぞいの流線についてエネルギー式を適用すると, 水の粘性を無視し，かつ，静水王分布を仮定すると次式をらる。

$$
\begin{aligned}
& \frac{\mathrm{ha}}{\mathrm{d}}=1+\frac{\mathrm{Fi}_{\mathrm{i}}{ }^{2}}{2} \\
& \mathrm{~F}_{\mathrm{i}}=\frac{\mathrm{Ub}}{\sqrt{\mathrm{g}^{\prime} \mathrm{d}}} \quad(\text { 内部フルード数 })
\end{aligned}
$$

ただし, $\mathrm{g}^{\prime}=\mathrm{g}\left(\rho_{1}-\rho_{2}\right) / \rho_{1}, \mathrm{~g}=$ 重力の加速度, $\mathrm{Ub}=$ 上層水が混入しない状態での澱み層排除孔の流速, $\mathrm{ha}=$ 排除孔 敷高より内部境界面までの高さである。澱み層から流出する流量は $\mathrm{Q} \mathrm{a}$ とすと, Ub= $\mathrm{Qa} / \mathrm{Bd}$ ，乙れを式 (2) 飞代入すると次式をうる。

$$
Q^{2} \mathrm{a}=2 \mathrm{~g}^{\prime} \mathrm{B}^{2} \mathrm{~d}^{2}(\mathrm{ha}-\mathrm{d})
$$

内部境界面の高さhaを与えたとを，下層水のみが流入する限界状態の条件は，式(4)をdで微分して，０とお $く$ と

$$
\mathrm{d} \leqq \frac{2}{3} \text { ha }
$$

で表わされる。したがって，澱み層排除孔から下層水のみを流す時の最大流量 Q $\mathrm{a} \cdot \max は$ は, 式(4), (5)より，

$$
\mathrm{Q} \mathrm{a} \cdot \max =\mathrm{B} \sqrt{\mathrm{g}^{\prime}\left(\frac{2}{3} \mathrm{ha}\right)^{3}}
$$

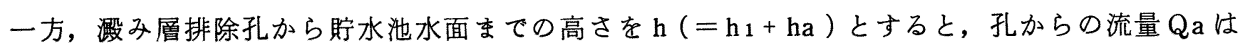

$$
\mathrm{Qa}=\mathrm{C}_{2} \mathrm{a} \sqrt{2 \mathrm{gh}} \quad\left(\mathrm{C}_{2}: \text { オリフィス流量係数, } \mathrm{a}: \text { 孔面積 }=\mathrm{Bd}\right)
$$

である。下層のみ排除するための条件は, 式(7)で求まるQaが式(6)の $\mathrm{Qa} \cdot \max$ よ小さくなくてはならない。

図 5 の場合を例にして, 試算すると, $\mathrm{h}_{1} \approx \mathrm{h}_{2}=40 \mathrm{~m}, \rho_{1}=1000 \mathrm{~kg} / \mathrm{m}^{3}\left(\right.$ 水温 $\left.10^{\circ} \mathrm{C}\right), \rho_{2}=998 \mathrm{~kg} / \mathrm{m}^{3}$ ( 水温 $20^{\circ} \mathrm{C}$ ) であるから, ha $=30 \mathrm{~m}$ と仮定すると, $\mathrm{Qa} \cdot \max / \mathrm{B}=\sqrt{9.8 \times 0.002 \times\left(\frac{2}{3} \times 30\right)^{3}}=12.7 \mathrm{~m}^{3} /$ $\mathrm{sec} / \mathrm{m}$ 。 また $\mathrm{C}_{2}=0.6$ とすると, $\mathrm{Qa} / \mathrm{B}=\mathrm{d} \times \sqrt{2 \times 9.8 \times(40+30)}=37 \mathrm{~m} / \mathrm{sec} / \mathrm{m}$ 。したがって $\mathrm{d}=$ $0.34 \mathrm{~m}(<30 \mathrm{~m})$ と計算される。以上のよらに, 澱み層を排除する場合の下流への放流水の平均濃度は, 上 層と下層の濃度をそれぞれ $\mathrm{C}_{1}, \mathrm{C}_{2}$ とすると，

$$
\mathrm{C}=\mathrm{C}_{1} \mathrm{Qa}+\mathrm{C}_{2}\left(\mathrm{Q}_{1}+\mathrm{Q}_{02}\right) /\left(\mathrm{Qa}+\mathrm{Q}_{1}+\mathrm{Q}_{02}\right)
$$

\section{4. 貯水池濁水放流が下流の濁り継続時間に及ぼす影響}

次に，澱み層排除孔の設置が下流河川の濁りに及深す影響を検討するために，K貯水池を対象にして鉊直 一次元の仮定のもとに数值シミュレーションを行なった。そのさいの水平層に関する基礎方程式は次のとう りである。

$$
\begin{aligned}
& \frac{\partial \mathrm{T}}{\partial \mathrm{t}}=\frac{(\alpha+\mathrm{D})}{\mathrm{A}} \frac{\partial}{\partial \mathrm{y}}\left(\mathrm{A} \frac{\partial \mathrm{T}}{\partial \mathrm{y}}\right)-\frac{1}{\rho \mathrm{CA}} \frac{\partial}{\partial \mathrm{y}}(\mathrm{A} \phi)-\frac{1}{\mathrm{~A}} \frac{\partial}{\partial \mathrm{y}}(\mathrm{VAT})+\frac{\mathrm{B}}{\mathrm{A}}\left(\mathrm{Ui} \mathrm{T}^{\prime} \mathrm{i}-\mathrm{Uo} \mathrm{T}\right) \\
& \frac{\partial \mathrm{C}}{\partial \mathrm{t}}=\frac{(\alpha+\mathrm{D})}{\mathrm{A}} \frac{\partial}{\partial \mathrm{y}}\left(\mathrm{A} \frac{\partial \mathrm{C}}{\partial \mathrm{y}}\right)-\frac{1}{\mathrm{~A}} \frac{\partial}{\partial \mathrm{y}}(\mathrm{VAC})+\frac{\mathrm{B}}{\mathrm{A}}\left(\mathrm{UiC}^{\prime} \mathrm{i}-\mathrm{UoC}\right)+\frac{1}{\mathrm{~A}} \frac{\partial}{\partial \mathrm{y}}(\mathrm{WoAC})-\frac{\mathrm{WoC}}{\mathrm{A}} \frac{\partial \mathrm{A}}{\partial \mathrm{y}} \cdots(1) \\
& \frac{\partial \mathrm{VA}}{\partial \mathrm{y}}=\mathrm{B}\left(\mathrm{Ui}-\mathrm{Uo}_{0}\right)
\end{aligned}
$$

ことに, $\mathrm{T}(\mathrm{y})$ : 標高 $\mathrm{y}$ の水温, $\mathrm{C}(\mathrm{y})$ : 標高 $\mathrm{y}$ の濁度, $\mathrm{Ui}(\mathrm{y})$ : 標高 $\mathrm{y}$ の流入水平流速, Uo $(\mathrm{y})$ : 標高 $\mathrm{y}$ の放流 水平流速, $\mathrm{V}(\mathrm{y})$ : 標高 $\mathrm{y}$ の鉊直流速, $\mathrm{Wo}$ : 眯濁粒子の沈降速度, $\mathrm{T}_{\mathrm{i}}^{\prime}$ : 標高 $\mathrm{y}$ の流入水量 $($ 連行後 $), \mathrm{C}_{\mathrm{i}}{ }^{\prime}$ : 標高 $\mathrm{y}$ の流入水濃度 (連行後)， $\mathrm{A}(\mathrm{y})$ : 標高 $\mathrm{y}$ の貯水池平面積, $\mathrm{B}(\mathrm{y})$ : 標高 $\mathrm{y}$ の貯水池平均幅, $\phi(\mathrm{y}):$ 標高 $\mathrm{y}$ 飞達する輻射熱, $\alpha$ : 分子拡散係数, $\mathrm{D}$ : 渦動拡散係数, $\rho$ : 水の密度, $\mathrm{C}:$ 水の比較, $\mathrm{t}$ : 時間 
ダムに設けた取水口と越流部に向ら眝水池内の流れの流速分布, おょび, 貯水池上流飞おける流入河川水の 流れの流速分布と流入層厚は, 安芸ら ${ }^{3)}$ の考え方に準じて, 式(9) (11)の基礎式を差分化し, 気象, 洪水流量, 発電所の運転に関する流量の值としてKダム貯水值における1978 年の 1 年間の実測データをインブットし て, 東京理科大学情報センタ一の計算機を用いて数值解析を行なった。放流水の水温の解析值と実測値との 比較を図 9 亿示す（紙面の関係で洪水時を中心とした前後の期間のみを図示した）。ついで, 貯水池からの 放流の条件を表 1 のうに変えて, それぞれの場合について水温と密度の分布と年間の変化の状態を解析し た。図 9, 図 10 中にその結果を示す。Case 1 の水温解析值は良い一致を示しており, をた, 溊み層排除

表 1 数值シミュレーションの条件

\begin{tabular}{|c|c|c|c|}
\hline Case & ダム越流部標高 & 発電所取水口標高 & 流 量 の 条 件 \\
\hline 1 & $281 \mathrm{~m}$ & $250 \mathrm{~m}$ & 1978 年の運転実績による。 \\
\hline 2 & $"$ & 230 & 発電所取水口流量はCase 1 と同じ \\
\hline 3 & $"$ & 281 & 同 上 \\
\hline
\end{tabular}

時に対応しているとみられるC ase 2 とC ase 1 の濁度の間には顕著差は認められない。その理由としては， 出水時においてはダム越流量が発電用水量の約 5 倍に達するために, 下流河川の濁度は越流水により支配さ れるとと, また, 出水時の底層部の濁度が表層部よりる必ずしる高くないととにょると考えられる。

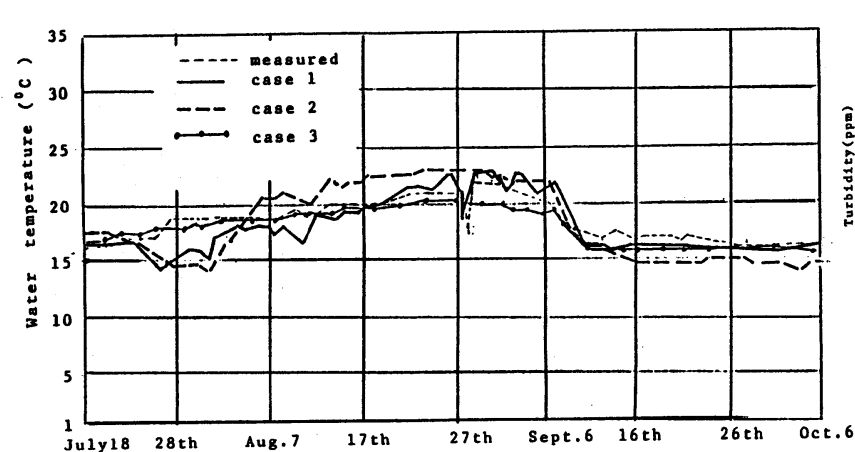

図 9 ダムからの放流条件が下流水温に及ぼす影響

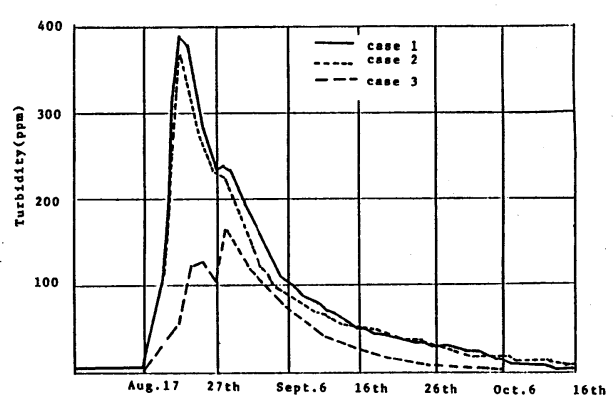

図 10 ダムからの放流水が下流濁度に及ぼす影響

\section{5. 結 語}

以上の検討結果を要約すると, 検討対象としたダム貯水池の場合, ( $\mathrm{i}$ )眝水池の密度分布は主として水温に 上り支配され，(ii)発電所取水口標高面飞安定度の高い内部境界面が形成される。(iii)㓋水出水時には, 界面は 破壊されるととるあるが, 出水後早い時期飞再び安定化する。しかし, 濁度の鉛直分布は相当長期飞亘り反 転状態を保つ。(iV)有機性のインパクトは下層の溊み層内飞停滞し易いので，ての層を排除することは水質劣 化を防ぐために効果的であり，その排除を洪水出水時飞行えば，下流飞及偠す影響を少なくおさえるととが 可能である。

\section{参 考 文 献}

1）安芸周一, 白砂孝夫：眝水池濁水現象の調查と解析, 電中研報告 74505, （1974）

2) Harleman, D.R.F et al : Submerged Sluice Control of Stratified Flow, Proc.ASCE. ( 1958 )

3) 1) K同じ 